\title{
Leaf Senescence and Protein Metabolism in Creeping Bentgrass Exposed to Heat Stress and Treated with Cytokinins
}

\author{
Mahalaxmi Veerasamy, Yali He, ${ }^{1}$ and Bingru Huang ${ }^{2}$ \\ Department of Plant Biology and Pathology, Rutgers University, New Brunswick, NJ 08901
}

\begin{abstract}
Additional Index words. Agrostis stolonifera, high temperature, chlorophyll, protease, photochemical efficiency
Abstract. Heat stress induces leaf senescence and causes changes in protein metabolism. The objective of this study was to investigate effects of exogenous application of a synthetic form of cytokinin, zeatin riboside (ZR), on protein metabolism associated with leaf senescence under heat stress for a cool-season grass species. Creeping bentgrass (Agrostis stolonifera L.) (cv. Penncross) plants were exposed to optimum temperature control $\left(20 / 15^{\circ} \mathrm{C}\right.$, day/night) and heat stress $\left(35 / 30^{\circ} \mathrm{C}\right)$ in growth chambers. Before heat stress treatments, foliage was sprayed with $10 \mu \mathrm{mol} Z \mathrm{ZR}$ or water (untreated) for 3 days and then once per week during 35 days of heat stress. Leaf chlorophyll content, photochemical efficiency $\left(F_{v} / F_{m}\right)$, and soluble protein content declined, whereas protease activity increased during heat stress. Treatments with $Z R$ helped maintain higher leaf chlorophyll content, $F_{v} / F_{m}$, and soluble protein content under heat stress. Protease activity in ZR-treated plants was lower than that of untreated plants. Zeatin riboside-treated plants had less severe degradation of ribulose-1,5-bisphosphate carboxylase proteins than untreated plants exposed to heat stress. In addition, ZR treatment upregulated the expression of 32- and 57-kDa proteins under heat stress conditions. These results demonstrated that the exogenous application of $\mathrm{ZR}$ ameliorated the negative effects of heat stress, as manifested by suppression or delay of leaf senescence. Cytokinins may have helped to alleviate heat stress injury, probably by slowing down the action of protease and by induction or upregulation of heat-shock proteins.
\end{abstract}

Temperatures greater than the optimal growth temperature negatively affect plant growth and induce various physiological and metabolic changes, including premature leaf senescence. Leaf senescence is characterized by loss of chlorophyll and proteins (Richmond and Lang, 1957; Selivankina et al., 2001). Heat stress has also been reported to accelerate the process of protein degradation (Gulen and Eris, 2004; He et al., 2005; Jiang and Huang, 2002). Under conditions of high temperature, protein loss is accelerated as a result of increased protease activity and this, in turn, leads to accelerated leaf senescence (Al-Khatib and Paulsen, 1984; Ueda et al., 2000; ZavaletaMancera et al., 1999). Plant adaptation to high temperatures also involves induction of protein synthesis or altered protein functions (Teeri, 1980). A family of proteins, called heat-shock proteins (HSPs), are often induced when plants are exposed to elevated temperatures. Heat-shock proteins are divided into two major classes based on their molecular size, with high-molecular mass HSPs ranging from 60 to $110 \mathrm{kDa}$ and low-molecular mass HSPs ranging between 15 and $30 \mathrm{kDa}$ (Vierling, 1991). These proteins protect biomolecules and organelles in plant cells from stress damage by enhancing thermotolerance (Park et al., 1996; Sun et al., 2002).

Different approaches have been examined in alleviating heat stress injury, including exogenous application of plant hormones, such as cytokinins. Cytokinins regulate many aspects of growth and development, including leaf senescence (Binns,

Received for publication 11 Oct. 2006. Accepted for publication 2 Feb. 2007. The authors thank Rutgers Center of Turfgrass for funding support of this research project.

Thanks also go to Dr. Jiang Tian, Steve McCann, Yan Xu, and Emily Merewitz for critical review of the manuscript.

${ }^{1}$ Current address: College of Agricultural and Biological Science, Shanghai Jiao Tong University, Shanghai, 201101, China.

${ }^{2}$ Corresponding author. E-mail: huang@aesop.rutgers.edu.
1994; Hare and Van Staden, 1997). Cytokinins have the ability to retard senescence, and this may be the result of their influence on different metabolic processes. Senescent leaves showed a decline in cytokinin level, and exogenous application of cytokinin resulted in delayed senescence in various plant species (Badenoch-Jones et al., 1996; Liu and Huang, 2002; Nooden et al., 1979). It has also been reported that transgenic tobacco (Nicotiana tabaccum L.) plants that overexpressed the isopentenyltransferase (ipt) gene controlling cytokinin synthesis showed increased cytokinin content, which resulted in delayed senescence (Gan and Amasino, 1995). Cytokinins prevent senescence and its accompanying chlorophyll breakdown by preventing proteolysis (Martin and Thimman, 1972) or by reducing the messenger RNA (mRNA) and protein level of proteases ( $\mathrm{Li}$ et al., 2000). Cytokinins inhibited the loss of proteins and prevented the increase in proteolytic activity of senescing leaves in Hordeum vulgare L. (Peterson and Huffaker, 1975). The enhancement in protein content of Tropaeolum majus L. leaves treated with cytokinin has been attributed to the inhibition of protein degradation (Mizrahi et al., 1970). Cytokinins are able to counteract the deleterious effect of heat stress, probably by scavenging free radicals or by modulating the activity of various antioxidant enzymes (Caers et al., 1985; Dhindsa et al., 1982; Lesham, 1984; Liu and Huang, 2002; Synkova et al., 2006; Wang et al., 2003).

Creeping bentgrass is a widely used cool-season turfgrass species and there is often a considerable decline in turfgrass quality resulting from leaf senescence under conditions of hightemperature stress. Previous studies have demonstrated that exogenous application of cytokinins to the root zone enhanced shoot and root growth and delayed leaf senescence (Liu and Huang, 2002; Liu et al., 2002). Foliar application of cytokinin may delay leaf senescence or promote better heat tolerance in creeping bentgrass by affecting protein metabolism. 
Understanding the relationship of cytokinins and heat-induced changes in protein metabolism may help elucidate their role in regulating heat tolerance. Therefore, the objective of this study was to determine the effects of an exogenous application of cytokinins on protein metabolism and leaf senescence for creeping bentgrass under heat stress.

\section{Materials and Methods}

Plant materials and growth conditions. Sod plugs of 'Penncross' creeping bentgrass were collected from 3-year-old field plots at the Rutgers University Horticulture Farm II (New Brunswick, NJ). They were transferred into PVC tubes $(10 \mathrm{~cm}$ in diameter and $30 \mathrm{~cm}$ long) filled with washed sand. Plants were maintained in a greenhouse for 2 months and then moved into growth chambers. The growth chamber conditions were set at a temperature of $20 / 15^{\circ} \mathrm{C}$ (day/night), $75 \%$ humidity, a $14-\mathrm{h}$ photoperiod, and $400 \mu \mathrm{mol} \cdot \mathrm{m}^{-2} \cdot \mathrm{s}^{-1}$ of photosynthetically active radiation. Plants were fertilized once per week with $100 \mathrm{~mL}$ half-strength Hoagland solution (Hoagland and Arnon, 1950) and cut once per week to the height of $\approx 5 \mathrm{~cm}$. Plants were allowed to acclimate to growth chamber conditions for $14 \mathrm{~d}$ before treatments were imposed.

Cytokinin And Temperature treatments. Plants were pretreated daily by foliar spray with $50 \mathrm{~mL}$ of water (untreated) or $50 \mathrm{~mL}$ (this volume saturated the canopy until some dripping occurred) of $10 \mu \mathrm{mol}$ zeatin riboside (ZR; ZR-treated) for $3 \mathrm{~d}$ before high-temperature treatment (heat stress) and on the day of heat stress initiation. Water and ZR (transzeatin riboside; Acros Organics, Fair Lawn, NJ) solution contained 0.05\% Tween 20 (Sigma-Aldrich, St. Louis) and was adjusted to a $\mathrm{pH}$ of 6.7 to -6.9 with $\mathrm{NaOH}$ or $\mathrm{HCl}$. After $3 \mathrm{~d}$ of pretreatment, both untreated and ZR-treated plants were then exposed to heat stress at $35 / 30{ }^{\circ} \mathrm{C}$ (day/night) for $35 \mathrm{~d}$ in the growth chamber. During heat stress treatment, plants were treated again with 50 $\mathrm{mL}$ of water or $10 \mu \mathrm{mol} Z \mathrm{R}$ once per week. Plants were watered with $200 \mathrm{~mL}$ water twice daily to prevent water deficit. The 10$\mu$ mol ZR concentration was used in this study because it has been found to be the most effective dose in alleviating heat injury in creeping bentgrass through root-zone injection (Liu and Huang, 2002). Plants grown under optimum temperature conditions at $20 / 15^{\circ} \mathrm{C}$ (day/night) were treated with water and used as a control for comparison with the heat-stressed plants.

Measurements. Two parameters, including leaf chlorophyll content and photochemical efficiency, were measured to evaluate leaf senescence and the severity of heat injury. All measurements were made on leaves at weekly intervals. Chlorophyll was extracted by soaking $0.1 \mathrm{~g}$ fresh leaves in $10 \mathrm{~mL}$ dimethyl sulfoxide for $72 \mathrm{~h}$. The absorbance of the extract was estimated at $663 \mathrm{~nm}$ and $645 \mathrm{~nm}$ with a spectrophotometer (Spectronic Genesys 2; Spectronic Instruments, Rochester, NY). Chlorophyll content was calculated according to the formula of Arnon (1949).

Leaf photochemical efficiency was determined by measuring chlorophyll fluorescence, the ratio of variable fluorescence to maximal fluorescence $\left(\mathrm{F}_{\mathrm{v}} / \mathrm{F}_{\mathrm{m}}\right)$, with a leaf photochemical efficiency analyzer (Fim 1500; ADC BioScientific, Hoddesdon, UK) according to the method described by Havaux (1992). When the leaf is kept in the dark, the amount of florescence is at the basal level $\left(\mathrm{F}_{0}\right)$; when the leaf is flashed with bright light, the florescence increases to a maximum $\left(\mathrm{F}_{\mathrm{m}}\right)$. The difference between the maximum and minimum fluorescence is the variable fluorescence $\left(F_{v}\right)$ and the ratio of $F_{v} / F_{m}$ is the photochemical efficiency of Photosystem II (PSII). Intact leaves were covered in specially designed leaf chambers and allowed to adapt in the dark for $30 \mathrm{~min}$ before measuring fluorescence. Measurement was made on three subsamples in each pot.

Protein extraction AND QUantification. Total soluble proteins were extracted from leaves according to the method of Shimoni et al. (1997). Leaf tissue ( $0.5 \mathrm{~g}$ fresh weight) was ground with liquid nitrogen to a fine powder. Protein was extracted in $3 \mathrm{~mL}$ buffer containing $0.10 \mathrm{~mm}$ Tris- $\mathrm{HCl}(\mathrm{pH}$, 7.6) and $0.15 \mathrm{M} \mathrm{NaCl}$. Samples were then centrifuged twice at $16,000 g_{\mathrm{n}}$ at $4{ }^{\circ} \mathrm{C}$ for $30 \mathrm{~min}$ and the resulting supernatant was collected. Protein content of leaves was quantified by the method of Bradford (1976) using bovine serum albumin as standard.

Protease activity measurement. Extracts were assayed according to a modified method of Benbella and Paulsen (1998). Fresh shoots $(1.0 \mathrm{~g})$ were ground to a fine powder in liquid nitrogen and placed in $4 \mathrm{~mL}$ extraction medium $(25 \mathrm{~mm}$ HEPES at a $\mathrm{pH}$ of $7.5,1 \mathrm{~mm}$ ethylenediamine tetraacetic acid, and $4 \mathrm{~mm}$ dithiothreitol). The homogenized samples were centrifuged twice at $16,000 \mathrm{~g}_{\mathrm{n}}$ at $4{ }^{\circ} \mathrm{C}$ for $30 \mathrm{~min}$. Crude protease activity was assayed by adding $0.1-\mathrm{mL}$ aliquots of enzyme extract to $1.5 \mathrm{~mL} 200 \mathrm{~mm}$ sodium citrate-citric acid buffer $(\mathrm{pH}, 5.2)$ and $0.4 \mathrm{~mL} \mathrm{1 \% (w/v)} \mathrm{azocasein.} \mathrm{The} \mathrm{reference}$ tube contained $0.1 \mathrm{~mL}$ extraction medium instead of enzyme extract. The tubes were incubated for $2 \mathrm{~h}$ at $37^{\circ} \mathrm{C}$. The reaction was stopped by adding $1 \mathrm{~mL} 15 \%(\mathrm{w} / \mathrm{v})$ trichloroacetic acid. Both sample and reference tubes were then incubated at $4{ }^{\circ} \mathrm{C}$ for $30 \mathrm{~min}$. The resulting precipitate was removed by centrifugation twice at $4000 g_{n}$ for $5 \mathrm{~min}$. The absorbance of clear supernatant was read at $340 \mathrm{~nm}$ in a spectrophotometer (Spectronic Genesys 2). The absorbance of reference was subtracted from the sample. One unit of enzyme activity was defined as the changes of absorbance by 0.1 .

Protein expression. Samples from 21-d heat-stressed leaves were analyzed for changes in protein expression by sodium dodecyl sulfate-polyacrylamide gel electrophoresis (SDS-PAGE) according to the method of Laemmili (1970), with slight modifications. Samples were solubilized in SDSPAGE sample buffer containing $75 \mathrm{~mm}$ Tris- $\mathrm{HCl}(\mathrm{Ph}, 6.8)$, $50 \%(\mathrm{w} / \mathrm{v})$ sucrose, $10 \%(\mathrm{w} / \mathrm{v})$ SDS, $20 \%(\mathrm{v} / \mathrm{v}) \beta$-mercaptoethanol, and $1 \%$ bromophenol blue. The ratio of sample to buffer volume was 4:1. Proteins were separated by discontinuous SDS-PAGE with an electrophoresis unit (Protein II; BioRad, La Jolla, CA) using a 6\% stacking gel and 12\% separating gel. Gels were stained overnight with Coomassie brilliant blue R-250. Gels for SDS-PAGE were run on three samples (replicates) for each treatment. The gel of one representative replicate is presented.

EXPERIMENTAL DESIGN AND STATISTICAL ANALYSIS. Cytokinin and temperature treatments were arranged in a randomized, complete block design, each with three replicates. Hightemperature treatment was repeated simultaneously in three growth chambers. Three tubes of plants for each treatment were placed inside each chamber as three subsamples. The mean of the three subsamples was used to represent a single replicate in the analysis of variance. Sampling was done at an interval of $7 \mathrm{~d}$ for the entire duration of experiment, which lasted for $35 \mathrm{~d}$. Data were analyzed by analysis of variance according to the general linear model procedures of SAS (SAS Institute, Cary, 
NC). Differences between untreated plants, ZR treatment, and nonstressed controls were separated by the LSD test at a 0.05 $P$ level.

\section{Results}

LEAF CHLOROPHYLL CONTENT. Leaf chlorophyll content of both ZR-treated and untreated plants decreased significantly after $7 \mathrm{~d}$ of heat stress $\left(35^{\circ} \mathrm{C}\right)$ compared with that at $20{ }^{\circ} \mathrm{C}$ (Fig. 1). The decrease in chlorophyll content at $7 \mathrm{~d}$ was $13 \%$ in heat-stressed plants treated with ZR and $20 \%$ in untreated plants. By $35 \mathrm{~d}$ of heat stress, chlorophyll content decreased by $39 \%$ in ZR-treated plants and $51 \%$ in untreated plants compared with nonstressed control plants grown at $20{ }^{\circ} \mathrm{C}$. During heat stress, ZR-treated plants had significantly higher chlorophyll content than untreated plants.

LEAF PHOTOCHEMICAL EFFICIENCY. Photochemical efficiency $\left(\mathrm{F}_{\mathrm{v}} / \mathrm{F}_{\mathrm{m}}\right)$ decreased significantly with heat stress, beginning at $7 \mathrm{~d}$ for untreated plants and $14 \mathrm{~d}$ for ZR-treated plants (Fig. 2).

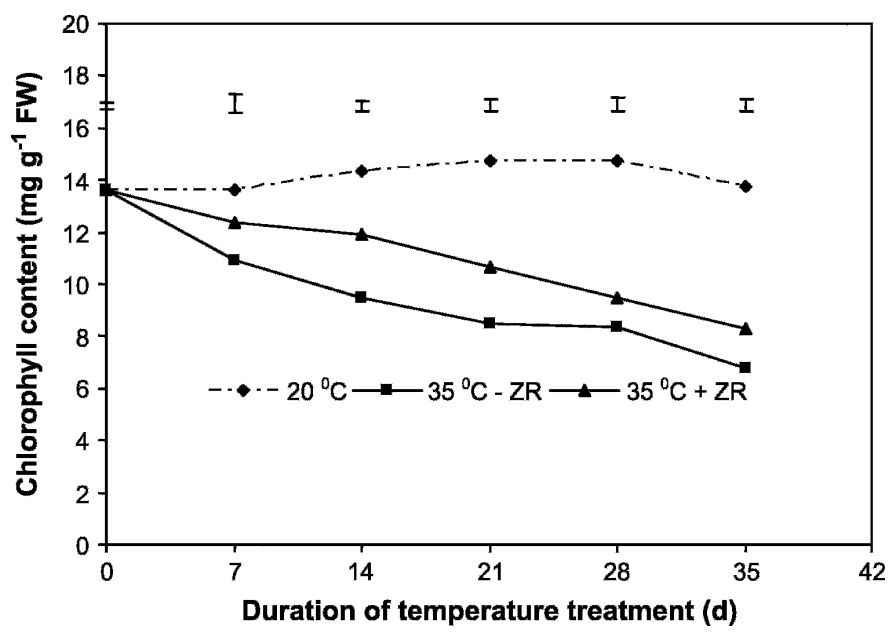

Fig. 1. Effect of zeatin riboside (ZR) on chlorophyll content of creeping bentgrass exposed to heat stress. Vertical bars are LSD values $(P \leq 0.05)$ for treatment comparisons at a given day of treatment. $\mathrm{FW}$, fresh weight.

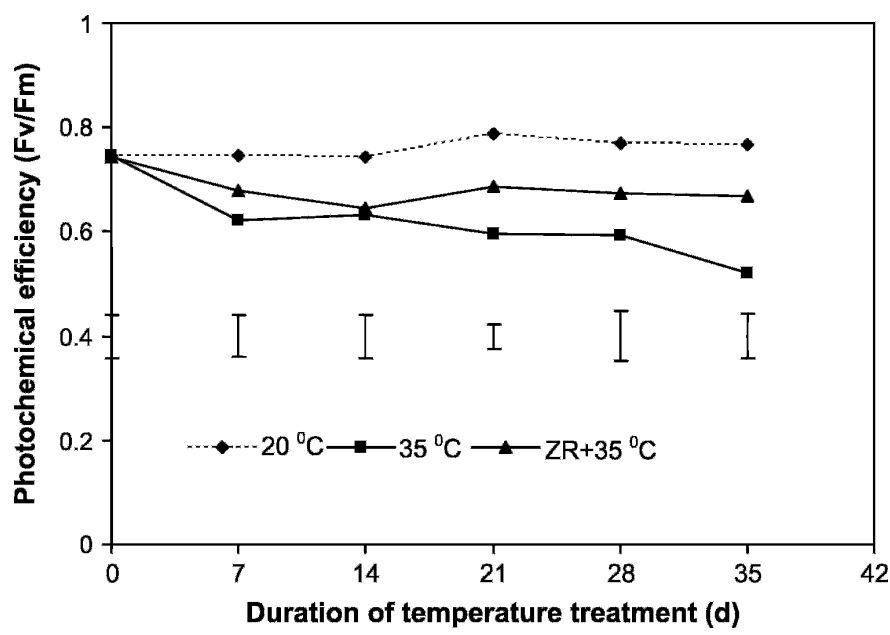

Fig. 2. Effect of zeatin riboside (ZR) on leaf photochemical efficiency of creeping bentgrass exposed to heat stress. Vertical bars are LSD values $(P \leq$ 0.05 ) for treatment comparisons at a given day of treatment.
The decline in $\mathrm{F}_{\mathrm{v}} / \mathrm{F}_{\mathrm{m}}$ at $7 \mathrm{~d}$ was $17 \%$ in untreated plants and $9 \%$ in plants treated with ZR, compared with nonstressed control plants. By $35 \mathrm{~d}$, the decline in $\mathrm{F}_{\mathrm{v}} / \mathrm{F}_{\mathrm{m}}$ was $32 \%$ in untreated plants and $13 \%$ in ZR-treated plants. Zeatin riboside-treated plants maintained a significantly higher $\mathrm{F}_{\mathrm{v}} / \mathrm{F}_{\mathrm{m}}$ than untreated plants at 21 and $35 \mathrm{~d}$ of heat stress.

Soluble PROTEIN CONTENT. Soluble protein content was significantly lower than control plants, beginning at $7 \mathrm{~d}$ for untreated plants and $14 \mathrm{~d}$ for ZR-treated plants (Fig. 3). Zeatin riboside-treated plants had significantly higher protein content than untreated plants at $21 \mathrm{~d}$ of heat stress. The difference in protein content between the treatments diminished at 28 and $35 \mathrm{~d}$.

Protease activity. Protease activity of both ZR-treated and untreated plants increased during heat stress compared with nonstressed control plants (Fig. 4). Zeatin riboside-treated plants had significantly lower protease activity than untreated plants at 21 and $35 \mathrm{~d}$ of heat stress. Protease activity at $21 \mathrm{~d}$ of heat stress was $15 \%$ higher in ZR-treated plants and 32\% higher in untreated plants compared with nonstressed plants. Toward

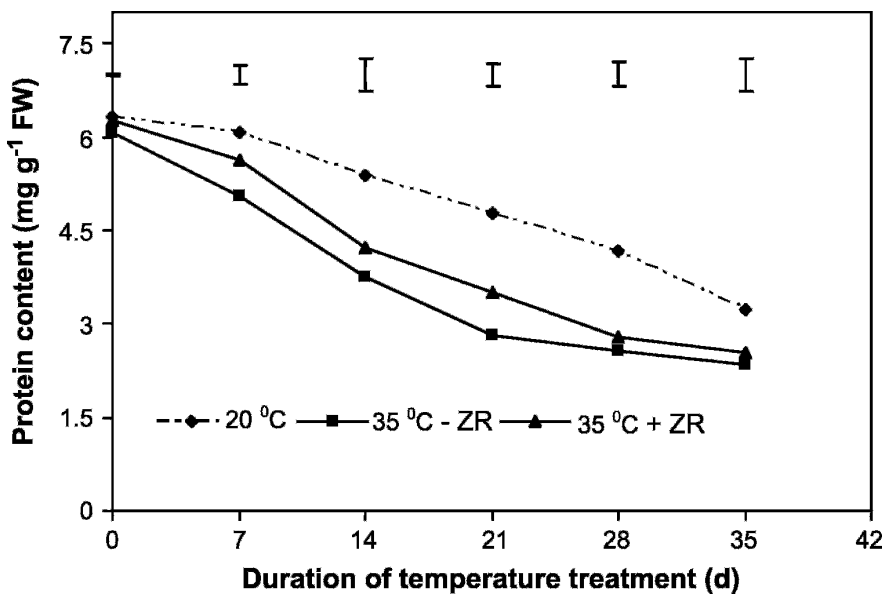

Fig. 3. Effect of zeatin riboside (ZR) on soluble protein content in leaves of creeping bentgrass exposed to heat stress. Vertical bars are LSD values $(P \leq$ 0.05 ) for treatment comparisons at a given day of treatment. $\mathrm{FW}$, fresh weight.

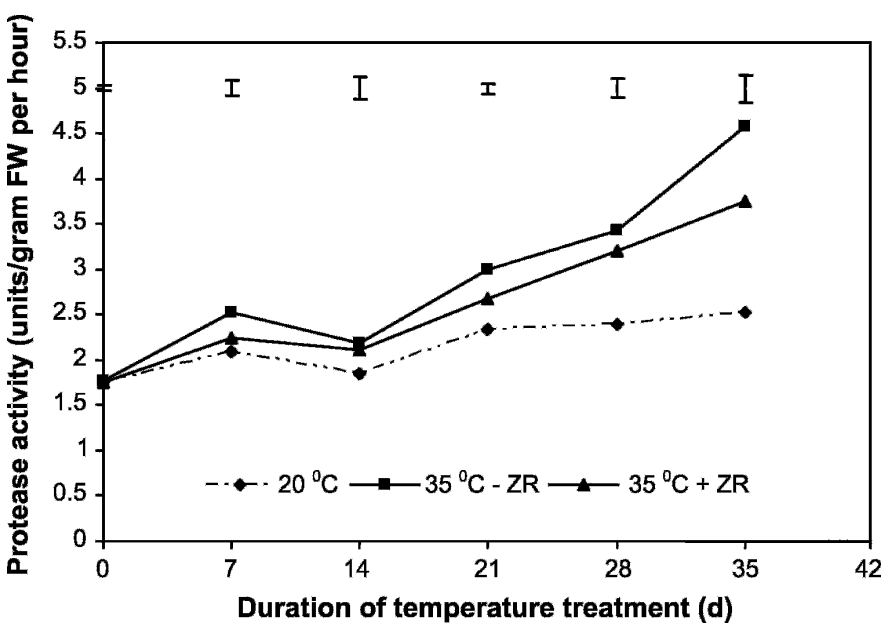

Fig. 4. Effect of zeatin riboside (ZR) on protease activity in leaves of creeping bentgrass exposed to heat stress. Vertical bars are LSD values $(P \leq 0.05)$ for treatment comparisons at a given day of treatment. FW, fresh weight. 
the end of the treatment period (day 35), protease activity was $81 \%$ higher in untreated plants and $48 \%$ higher in plants treated with ZR compared with plants grown at $20^{\circ} \mathrm{C}$.

Protein changes. Leaf protein SDS-PAGE showed effects of heat stress and ZR application on protein expression at $21 \mathrm{~d}$ (Fig. 5). Heat stress caused degradation of the large subunit of Ribulose-1,5-bisphosphate (RuBP)-carboxylase proteins (55 $\mathrm{kDa}$ ), and also increased the intensity of small-molecular weight proteins at $23 \mathrm{kDa}$. Exogenous application of $\mathrm{ZR}$ in heat-stressed plants upregulated several proteins, including 23 , 32 , and $57 \mathrm{kDa}$. The $57-\mathrm{kDa}$ proteins were present only in ZRtreated plants under heat stress. Zeatin riboside-treated plants had less severe degradation of RuBP-carboxylase proteins $(55 \mathrm{kDa})$ than untreated plants exposed to heat stress.

\section{Discussion}

Heat stress at $35{ }^{\circ} \mathrm{C}$ induced leaf senescence in creeping bentgrass, as indicated by the decline in chlorophyll content and photochemical efficiency. Results from this study confirmed results from previous studies with creeping bentgrass ( $\mathrm{Fu}$ and Huang, 2003; Liu and Huang, 2000). Heat-induced senescence has also been reported in other plant species (Crafts-Brandner and Salvucci, 2002; Yamasaki et al., 2002). Foliar application of the synthetic cytokinin ZR helped maintain higher chlorophyll concentration and photochemical efficiency for a longer duration of heat stress, suggesting that cytokinin delayed and suppressed leaf senescence induced by heat stress. Exogenous application of ZR into the root zone also suppressed the decrease in chlorophyll content and photochemical efficiency when roots were exposed to high soil temperatures (Liu and Huang, 2000). The effects of ZR on leaf senescence through foliar or root-zone application may be a result of increased chlorophyll synthesis, reduced chlorophyll degradation, or a

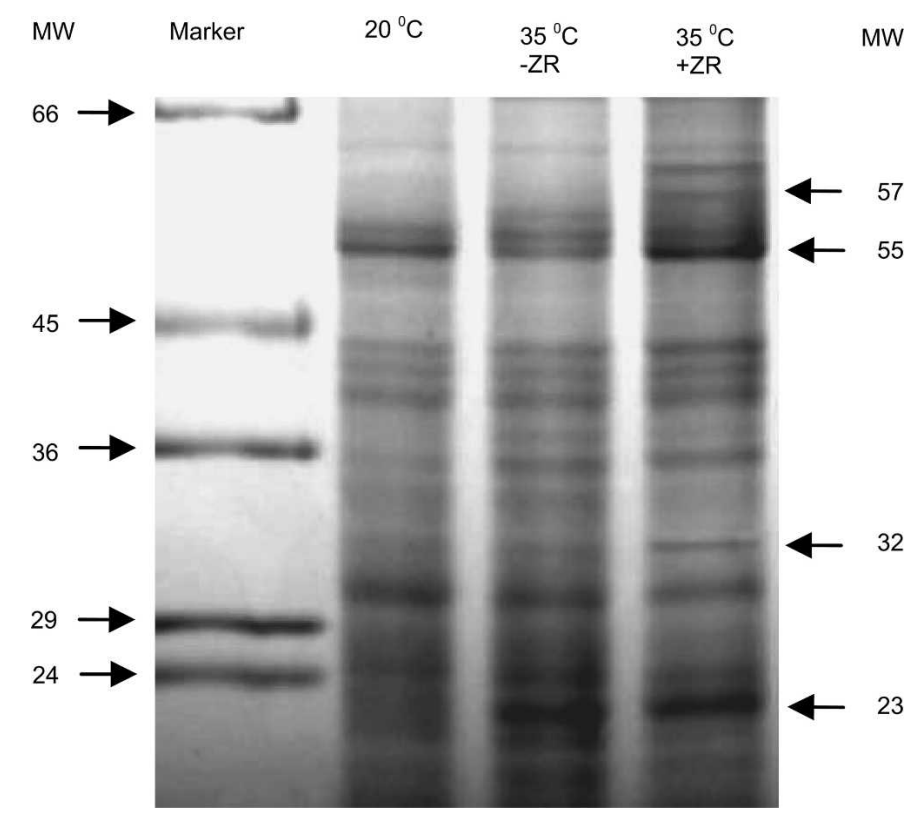

Fig. 5. Sodium dodecyl sulfate-polyacrylamide gel electrophoresis profile of soluble protein for creeping bentgrass exposed to heat stress for $21 \mathrm{~d}$ and treated with zeatin riboside (ZR). Equal amounts of protein were loaded in each lane. MW, molecular weight in kilodaltons. combination of both these factors (Fletcher et al., 1973; Genkov et al., 1997).

The alleviation of heat-induced senescence by cytokinins may be associated with alteration in protein degradation. It has been reported that chlorophyll loss is linked to protein degradation (Hashimoto et al., 1989). Our results showed that total soluble protein content was greatly reduced by heat stress. This is consistent with earlier reports that showed a decline in total soluble protein under conditions of heat stress in other plant species (Chaitanya et al., 2001; Key et al., 1981). It has been suggested that the progressive decline in protein content of leaves may be the result of a general decrease in synthesis or the result of enhanced proteolytic degradation (Hieng et al., 2004; Zavaleta-Mancera et al., 1999). Decrease in protein content was accompanied by increased activity of serine proteases in senescent leaves of Phaseolus vulgaris L. (Huffaker, 1990). In our experiment, heat-stressed plants treated with ZR maintained higher total soluble protein content than untreated plants. Heat-stressed plants also showed higher levels of protease activity, and treatment with ZR resulted in lower protease activity. These results suggested that ZR may have delayed or suppressed heat-induced leaf senescence of creeping bentgrass by inhibiting proteolytic activities. Cytokinins may delay senescence by reducing the mRNA and protein levels of proteases (Jiang et al., 1999; Li et al., 2000). Cytokinins may also inhibit the activation of proteases during senescence. It has been reported that treatment with protease inhibitors resulted in delayed senescence in other plant species (Park and Doorn, 2005; Wang et al., 2004). The expression of most senescenceassociated genes was repressed by cytokinins (Hajouj et al., 2000; Weaver et al., 1998).

Tolerance to heat stress involves mechanisms that protect biomembranes, organelles, and molecules that enable them to maintain their functions, and HSPs play an important role in these mechanisms (Vishwanathan and Khanna-Chopra, 1996). Our study showed the synthesis of small HSPs of 23 and $32 \mathrm{kDa}$ was upregulated under heat stress, particularly when plants were treated with ZR, which may contribute to heat stress adaptation. The accumulation of 23-kDa proteins has also been reported in tomato (Lycopersicon esculentum L.) plants exposed to heat stress (Liu and Shono, 1999). The synthesis of $32-\mathrm{kDa}$ D1 protein was observed in P. vulgaris leaves during senescence (Roberts et al., 1987), which may be a result of preferential sequestration of ribosomes by psb A transcript (Droillard et al., 1992). Both 23- and 32-kDa proteins are located in PSII, and are involved in the light-driven oxidation of water in photosynthesis (Seidler, 1996). Our results suggest that the upregulation of $23-$ and $32-\mathrm{kDa}$ proteins in PSII by application of ZR could contribute to increased photochemical efficiency, as indicated by a higher $\mathrm{F}_{\mathrm{v}} / \mathrm{F}_{\mathrm{m}}$ ratio in $\mathrm{ZR}$-treated than untreated plants. It has been previously reported that increases in synthesis of small HSPs is positively correlated with whole-plant tolerance to heat stress (Park et al., 1996). Heat-stressed plants treated with ZR showed the accumulation of $57-\mathrm{kDa}$ proteins. The accumulation of a $57-\mathrm{kDa}$ protein, which is considered to be a subunit of $130-\mathrm{kDa}$ cytokininbinding protein complex (CBP 130) has been reported in the leaves of $N$. sylvestris Speg. and Comes (Mitsui et al.,1993). It is possible that these ZR-induced polypeptides may contribute toward thermotolerance in plants treated with ZR.

In conclusion, foliar application of cytokinin ZR delayed heat-induced leaf senescence or promoted heat tolerance of 
creeping bentgrass, as manifested by maintaining higher chlorophyll content and photochemical efficiency. Cytokinins may have helped to keep plants from heat stress injury by induction of HSPs that protect cellular functions or slow the action of proteases that cause breakdown of proteins. Any means that promote cytokinin synthesis would be beneficial for maintaining stay-green leaves and improving heat tolerance of cool-season turfgrass.

\section{Literature Cited}

Al-Khatib, K. and G.M. Paulsen. 1984. Mode of high temperature injury to wheat during grain development. Physiol. Plant. 61:363-368.

Arnon, D. 1949. Copper enzymes in isolated chloroplasts. Plant Physiol. 24:1-15.

Badenoch-Jones, J.P.C., D.S. Letham, and S. Singh. 1996. Effects of cytokinins supplied via the xylem at multiples of endogenous concentrations on transpiration and senescence in derooted seedlings of oat and wheat. Plant Cell Environ. 19:504-516.

Benbella, M. and G.M. Paulsen. 1998. Efficacy of treatments for delaying senescence of wheat leaves: I. Senescence under controlled conditions. Agron. J. 90:329-332.

Binns, A.N. 1994. Cytokinin accumulation and action: Biochemical, genetic and molecular approaches. Plant Mol. Biol. 45:173-176.

Bradford, M.M. 1976. A rapid and sensitive method for the quantification of microgram quantities protein using the principle of proteindye binding. Ann. Biochem. 72:248-254.

Caers, M., P. Rudelsheim, H. Van Onckelen, and S. Horemans. 1985. Effect of heat stress on photosynthetic activity and chloroplast ultrastructure in correlation with endogenous cytokinin concentration in maize (Zea mays L.) seedlings. Plant Cell Physiol. 26:47-52. Chaitanya, K.V., D. Sundar, and A.R. Reddy. 2001. Mulberry leaf metabolism under high temperature stress. Biol. Plant. 44:379-384. Crafts-Brandner, S.J. and M.E. Salvucci. 2002. Sensitivity of photosynthesis in a $\mathrm{C}_{4}$ plant, maize, to heat stress. Plant Physiol. 129:1773-1780.

Dhindsa, R.S., P.L. Plumb-Dhindsa, and D.M. Reid. 1982. Leaf senescence and lipid peroxidation: Effects of some phytohormones and scavengers of free radicals and singlet oxygen. Physiol. Plant. 56:453-457.

Droillard, M.J., N.J. Bate, S.J. Rothstein, and J.E. Thompson. 1992. Active translation of D-1 protein of photosystem II in senescing leaves. Plant Physiol. 99:589-594.

Fletcher, R.A., C. Teo, and A. Ali. 1973. Stimulation of chlorophyll synthesis in cucumber cotyledons by benzyladenine. Can. J. Bot. 51:937-939.

Fu, J.M. and B. Huang. 2003. Effects of foliar application of nutrients on heat tolerance of creeping bentgrass. J. Plant Nutr. 26:81-96.

Gan, S.S. and R.M. Amasino. 1995. Inhibition of leaf senescence by autoregulated production of cytokinin. Science 270:1986-1988.

Genkov, T., P. Tsoneva, and J. Ivanova. 1997. Effect of cytokinins on photosynthetic pigments and chlorophyllase activity in vitro cultures of axillary buds of Dianthus caryophyllus L. J. Plant Growth Regulat. 16:169-172.

Gulen, H. and A. Eris. 2004. Effect of heat stress on peroxidase activity and total protein content in strawberry plants. Plant Sci. 166:739-744.

Hajouj, T., R. Michelis, and S. Gepstein. 2000. Cloning and characterization of receptor like protein kinase gene associated with senescence. Plant Physiol. 124:1305-1314.

Hare, P.D. and J. Van Staden. 1997. The molecular basis of cytokinin action. Plant Growth Regulat. 23:41-78.

Hashimoto, H., M. Kurra-Hotta, and S. Katoh. 1989. Changes in protein content and in the structure and number of chloroplasts during leaf senescence in rice seedlings. Plant Cell Physiol. 30:707-715.

Havaux, M. 1992. Stress tolerance of photosystem II in vivo. Antagonistic effects of water, heat, and photoinhibition stresses. Plant Physiol. 100:424-432.
He, Y.L., X.Z. Liu, and B. Huang. 2005. Changes in protein content, protease activity, and amino acid content associated with heat injury in creeping bentgrass. J. Amer. Soc. Hort. Sci. 130:842-847.

Hieng, B., K. Ugrinovic, J.S. Vozlic, and M. Kidric. 2004. Different classes of protease are involved in the response to drought of Phaseolus vulgaris L. cultivars differing in sensitivity. J. Plant Physiol. 161:519-530.

Hoagland, C.R. and D.I. Arnon. 1950. The solution culture method for growing plants without soil. Calif. Agr. Expt. Circ. 347:1-32.

Huffaker, R.C. 1990. Proteolytic activity during senescence of plants. New Phytol. 116:199-231.

Jiang, Y. and B. Huang. 2002. Protein alteration in tall fescue in response to drought stress and abscisic acid. Crop Sci. 42:202-207.

Jiang, W.B., A. Lers, E. Lomaniec, and N. Aharoni. 1999. Senescence related serine protease in parsley. Phytochemistry 50:377-382.

Key, J.L., C.Y. Lin, and Y.M. Chen. 1981. Heat shock proteins in higher plants. Proc. Natl. Acad. Sci. USA 78:3526-3530.

Laemmili, U.K. 1970. Cleavage of structure proteins during the assembly of the head of bacteriophage T4. Nature 227:680-685.

Lesham, Y.Y. 1984. Interaction of cytokinin with lipid associated oxy free radicals during senescence: A prospective mode of cytokinin action. Can. J. Bot. 62:2943-2949.

Li, Q., A.J.E. Bettany, I. Donnison, C.M. Griffiths, H. Thomas, and I.M. Scott. 2000. Characterization of cysteine protease cDNA from Lolium multiflorum leaves and its expression during senescence and cytokinin treatment. Biochim. Biophys. Acta 1492:233-236.

Liu, X. and B. Huang. 2000. Heat stress injury in relation to membrane lipid peroxidation in creeping bentgrass. Crop Sci. 40:503-510.

Liu, X. and B. Huang. 2002. Cytokinin effects on creeping bentgrass response to heat stress: II. Leaf senescence and antioxidant metabolism. Crop Sci. 42:466-472.

Liu, X., B. Huang, and G. Banowetz. 2002. Cytokinin effects on creeping bentgrass responses to heat stress. I. Shoot and root growth. Crop Sci. 42:457-465.

Liu, J. and M. Shono. 1999. Characterization of mitochondria located small heat shock protein from tomato (Lycopersicon esculentum). Plant Cell Physiol. 40:1297-1304.

Martin, C. and K.V. Thimman. 1972. The role of protein synthesis in the senescence of leaves. I. The formation of protease. Plant Physiol. 49:64-71.

Mitsui, S., T. Wakasugi, and M. Sugiura. 1993. A cDNA encoding the $57 \mathrm{kDa}$ subunit of a cytokinin-binding complex from tobacco: The subunit has high homology to S-adenosyl-L-homocysteine. Plant Cell Physiol. 34:1089-1096.

Mizrahi, Y., J. Amir, and A.E. Richmond. 1970. The mode of action of kinetin in maintaining the protein content of detached Tropaeolum majus leaves. New Phytol. 69:355-361.

Nooden, L.D., G.M. Kahanak, and Y. Okatan. 1979. Prevention of monocarpic senescence in soybeans with auxin and cytokinin: An antidote of self destruction. Science 206:841-843.

Park, C. and W.G. Doorn. 2005. Delay of iris flower senescence by protease inhibitors. New Phytol. 165:473-480.

Park, S.Y., R. Shivaji, J.V. Krans, and D.S. Luthe. 1996. Heat-shock response in heat-tolerant and nontolerant variants of Agrostis palustris Huds. Plant Physiol. 111:515-524.

Peterson, L.W. and R.C. Huffaker. 1975. Loss of ribulose 1,5diphosphate carboxylase and increase in proteolytic activity during senescence of detached primary barley leaves. Plant Physiol. 55:1009-1015.

Richmond, A.E. and A. Lang. 1957. Effect of kinetin on protein content and survival of detached Xanthium leaves. Science 125: 650-651.

Roberts, D.R., J.E. Thompson, E.D. Dumbroff, S. Gepstein, and A.K. Matoo. 1987. Differential changes in the synthesis and steady state levels of thylakoid proteins during bean leaf senescence. Plant Mol. Biol. 9:343-353.

Seidler, A. 1996. The extrinsic polypeptides of Photosystem II. Biochim. Biophys. Acta 1277:35-60. 
Selivankina, S.Y., N.N. Karavaiko, D. Kuiper, G.V. Novikova, and O.N. Kulaeva. 2001. Cytokinin activity of zeatin allelic phosphate, a natural compound. Plant Growth Regulat. 33:157-164.

Shimoni, Y., A.E. Blechel, O.D. Anderson, and G. Galili. 1997. A recombinant protein of two high molecular weight glutenins alters gluten polymer formation in transgenic wheat. J. Biol. Chem. 272:15488-15495.

Sun, W., M. Van Montagu, and N. Verbruggen. 2002. Small heat shock proteins and stress tolerance in plants. Biochim. Biophys. Acta 1577:1-9.

Synkova, H., S. Semoradova, R. Schnablova, E. Witters, M. Husak, and R. Valcke. 2006. Cytokinin-induced activity of antioxidant enzymes in transgenic Pssu-ipt tobacco during plant ontogeny. Biol. Plant. 50:31-41.

Teeri, J.A. 1980. Adaptation of kinetic properties of enzymes to temperature variability, p. 251-260. In: N.L. Turner and P.J. Kramer (eds.). Adaptation of plants to water and high temperature stress. Wiley-Interscience, New York.

Ueda, T., S. Seo, Y. Ohashi, and J. Hashimoto. 2000. Circadian and senescence enhanced expression of a tobacco cysteine protease gene. Plant Mol. Biol. 44:649-657.

Vierling, E. 1991. The roles of heat shock proteins in plants. Annu. Rev. Plant Physiol. Plant Mol. Biol. 42:579-620.
Vishwanathan, C. and R. Khanna-Chopra. 1996. Heat shock proteins: Role in thermotolerance of crop plants. Curr. Sci. 71: 275-284.

Wang, Z., J. Pote, and B. Huang. 2003. Responses of cytokinins, antioxidant enzymes, and lipid peroxidation in shoots of creeping bentgrass to high root-zone temperatures. J. Amer. Soc. Hort. Sci. 128:648-655.

Wang, Y.T., C.Y. Yang, Y. Chen, Y. Lin, and J. Shaw. 2004. Characterization of senescence associated proteases in post harvest broccoli florets. Plant Physiol. Biochem. 42:663-670.

Weaver, L.M., S. Gan, B. Quirino, and R.M. Amasino. 1998. A comparison of the expression patterns of several senescence associated genes in response to stress and hormone treatment. Plant Mol. Biol. 37:455-469.

Yamasaki, T., T. Yamakawa, Y. Yamane, H. Koike, K. Satoh, and S. Katoh. 2002. Temperature acclimation of photosynthesis and related changes in photosystem II electron transport in winter wheat. Plant Physiol. 128:1087-1097.

Zavaleta-Mancera, H.A., K.A. Franklin, H.J. Ougham, H. Thomas, and I.M. Scott. 1999. Regreening of senescent Nicotiana leaves I. Reappearance of NADPH-protochlorophyllide oxidoreductase and light harvesting chlorophyll $\mathrm{a} / \mathrm{b}$ binding protein. J. Expt. Bot. 50:1677-1682. 